\title{
At vandre i takt: om paraders og processioners rituelle betydning
}

\author{
Et durkheimsk perspektiv
}

ANDERS KLOSTERGAARD PETERSEN

ENGLISH ABSTRACT: The purpose of this essay is to cast light on a previously under-acknowledged phenomenon in the history of religions and the phenomenology of religion. First, I suggest a heuristic typological distinction between parades and processions. Potentially, the differentiation between the two may be linked to a different origin and partly to a different intrinsic relationship to two diverse types of religion. Whereas parades are inherently related to hunter-gatherers' forms of religion and cosmic and global types of religion, processions, I surmise, are intrinsically related to urban forms of religion. The distinction, however, is of the nature of an idealtype. Secondly, I include a trajectory of scholarship in ritual studies that has not featured largely in the history of scholarship on ritual in either anthropology or the study of religion. I argue that parading and joint processions may give us a clue to the social efficacy of ritual and its biological underpinnings: Doing the drill enhances social bonding. My point is of a basic Durkheimian nature, but I take Durkheim a step further by undergirding his ritual and cultic understanding with a primatological and biological basis.

DANSK RESUME: I artiklen retter jeg opmærksomheden mod to forhold. For det første foreslår jeg en typologisk skelnen mellem parade og procession og argumenterer for, at de har baggrund $i$ to forskellige religionstyper. Mens processionen hidrorer fra by-eller arkaisk religion og forudsætter templet og offerinstitutionen som religionens omdrejningspunkt, er paraden knyttet til jæger-samler-religion, men fär en renæssance $i$ kosmos- og globalreligion. For det andet inddrager jeg en forskningstradition inden for ritualstudier, som underligt nok ikke har spillet nogen fremtrædende rolle $i$ den antropologiske og religionsvidenskabelige ritualforskning, men til gengæld er betydningsfuld $i$ den sociologiske litteratur. I tæt sammenhæng med mine aktuelle forskningsinteresser argumenterer jeg for, at der i denne tradition ikke alene ligger et betydeligt potentiale for at forstå ritualers socialt positive (og lejlighedsvis negative) betydning, men også deres basalbiologiske grundlag. På sin vis forsøger jeg $i$ artiklen at underbygge den durkheimske grundopfattelse af kultur, samfund og religion med et 
biologisk primatologisk fundament. Heri ligger ingen kritik af Durkheim; men derimod en udvidelse og underbygning.

KEYWORDS: typology; parade; procession; urban religion; cosmic and global religion; rituals of interaction; chimpanzees; bonobos; synchronisation; mirror neurons.

\section{Præludium: Eksempelmateriale}

Jeg kan huske, hvordan jeg for mange år siden som tilskuer deltog i en Fourth of July-parade i Brownsville, Texas, på grænsen til Mexico. Den ene store blomstersmykkede flåde efter den anden passerede forbi tilskuerne, som stod opstillet i Brownsvilles hovedgade. På de enkelte langsomt kørende flåder sad udklædte personer, som portrætterede afgørende begivenheder eller skikkelser i USA's historie. Tilsvarende boede jeg for en del år siden i Jerusalem. I forbindelse med indvielsen af den hellige ild i Opstandelseskirken (Ekklēsia tēs anastaseōs) eller Gravkirken (Ecclesia Sancti Sepulchri), som den kaldes blandt katolikker og protestanter, deltog jeg i 1994 i ildprocessionen, indvielsen af den nye ild: Hagion phōs. Det er et væsentligt ritual i både de østligt-ortodokse (som fx den græsk-ortodokse, den russisk-ortodokse og den serbisk-ortodokse) og orientalsk-ortodokse kirker (de koptisk-, syrisk- og armensk-ortodokse kirker), der opfatter det som et årligt tilbagevendende mirakel. Ildritualet falder på Store- eller Helliglørdag inden Påskesøndag, altså umiddelbart forud for første søndag efter forårsjævndøgn og den jødiske påskefejring (til forskel fra placeringen i Den romersk-katolske og de protestantiske kirker). ${ }^{1}$ Her ikke alene skabes, men også indvies den ild, som anvendes i samtlige østligt og orientalsk ortodokse kirker frem mod Helliglørdag det efterfølgende kalenderår (eneste undtagelse er den sidste orientalsk-ortodokse kirke: Den etiopisk-ortodokse Kirke).

Ifølge traditionen forsegler myndighederne Jesus' grav med voks. Under osmannertiden var det de lokale magthavere, i dag er det israelerne. Det skal sikre, at der ikke snydes med miraklet. Myndighederne indtager på denne måde rituelt en rolle svarende til romernes forsegling af Jesus' grav (Matt 27,65f.). Allerede Langfredag begynder menneskemængder at stimle sammen ved Opstandelseskirken. De palæstinensisk kristne, som for størstedelen er græsk-ortodokse, synger på Helliglørdag fra morgenstunden på arabisk: "Vi er de kristne, vi har været her i århundreder, og vi skal forblive her i evighed - Amen". Samtidig danser de unge mænd skulder ved skulder omkring Det Hellige Ciborium (selve bygningen over graven), mens andre sidder på skuldrene af dem og spiller højlydt på trommer. Der er en infernalsk larm, som skal forberede skaren på det efterfølgende mirakel - og, tilføjer jeg, skabe den durkheimske effervescens.

1 I den romersk-katolske kirkes påskefejring, som også de protestantiske kirker følger, er påskesøndag placeret første søndag efter første fuldmåne efter forårsjævndøgn. Som bekendt er kalenderspørgsmål en oplagt måde rituelt at markere forskel til tæt beslægtede, men rivaliserende former for religion. 
Først på eftermiddagen ankommer patriarken, hvorpå der bliver helt stille. Han bryder voksvæggen, går ind i selve gravkammeret og efter en bøn sker - i den ortodokse forståelse - miraklet. På den stenplade, der ifølge traditionen hviler over Jesus' grav, opstår en flamme med blåt lys. Patriarken tænder to lys med flammen og skænker som de første den koptiske og den armenske patriark den nye ild. Det er selvsagt en rituel forbrødringshandling mellem de to store ortodokse kirker, den østligt-ortodokse og den orientalsk-ortodokse. ${ }^{2}$ Herefter breder ilden sig overalt i kirken og udenfor. Det er et under, at Opstandelseskirken endnu ikke er brudt ud i brand i forbindelse med dette ritual. Der er ild og enorme brændende kærter overalt, og man skal i den grad vare sig for ikke at få sit hår svedet eller brændt af, skønt ilden ifølge den ortodokse tradition ikke brænder. Derfor 'bader' særligt de unge mandlige pilgrimme sig også i den for at vise dens mirakuløse egenskab - et 'costly signal', som vi plejer at kalde det religionsvidenskabeligt og evolutionsbiologisk. Signaler, som på den ene eller anden måde er kostbare for en selv (som fx påført lidelse som i piercing af kroppen, afgivelse af værdier som penge, eller rituel korsfæstelse), udtrykker indeksikalt tilhørsforholdet til gruppen og dens værdier og mindsker dermed risikoen for gratisme, snylteri og bedrageri mod fællesskabet. Det findes overalt i naturen som i hanpåfuglens fjerpragt eller blandt hanhugorme, der inden parringssæsonen svirrer i luften for at signalere deres overlegne sædkvalitet. Begge gør sig gennem deres maskulinitetspositur sårbare over for rovdyr (jf. Zahavi 1975; 1977). Det er, som ikke mindst William Irons og Richard Sosis har vist, et element, som også spiller en afgørende rolle for menneskelige fællesskaber og i den sammenhæng ritualiseret adfærd i forbindelse med religion (Irons 2001; Sosis 2000; 2003).

Fra Jerusalem transporters ilden med fly videre til en række ortodokse lande som fx Grækenland, hvor ilden ankommer til Athen for derfra at blive bredt ud til hele Den Ortodokse Kirke i Grækenland. Ved særlige processioner bæres ilden ind i de enkelte kirker, og alterlysene for det kommende år tændes. På denne måde markerer tændingen af alterlysene ikke blot begyndelsen af et nyt påskeår, men også enheden i den ortodokse kirke. Det er en og den samme ild, som brænder på alteret i samtlige ortodokse kirker verden over. Samtidig er denne ild indeksikalt horisontalt forbundet med Jesus' grav og Jerusalem og vertikalt med den himmelske verdens ild, hvor fra ildunderet udgår.

2 Adskillelsen mellem de østligt- og orientalsk-ortodokse kirker skyldes ud over magtstridigheder i det femte og sjette århundrede e.v.t. også en grundlæggende uoverensstemmelse i kristologien. De orientalsk-ortodokse kirker argumenterer for en monofysitisk forståelse af Kristus' natur (de afviser selv denne betegnelse og kalder det i stedet for miafysitisme) vendt mod den kalkedonensiske opfattelse af Kristus som både gud og menneske. 


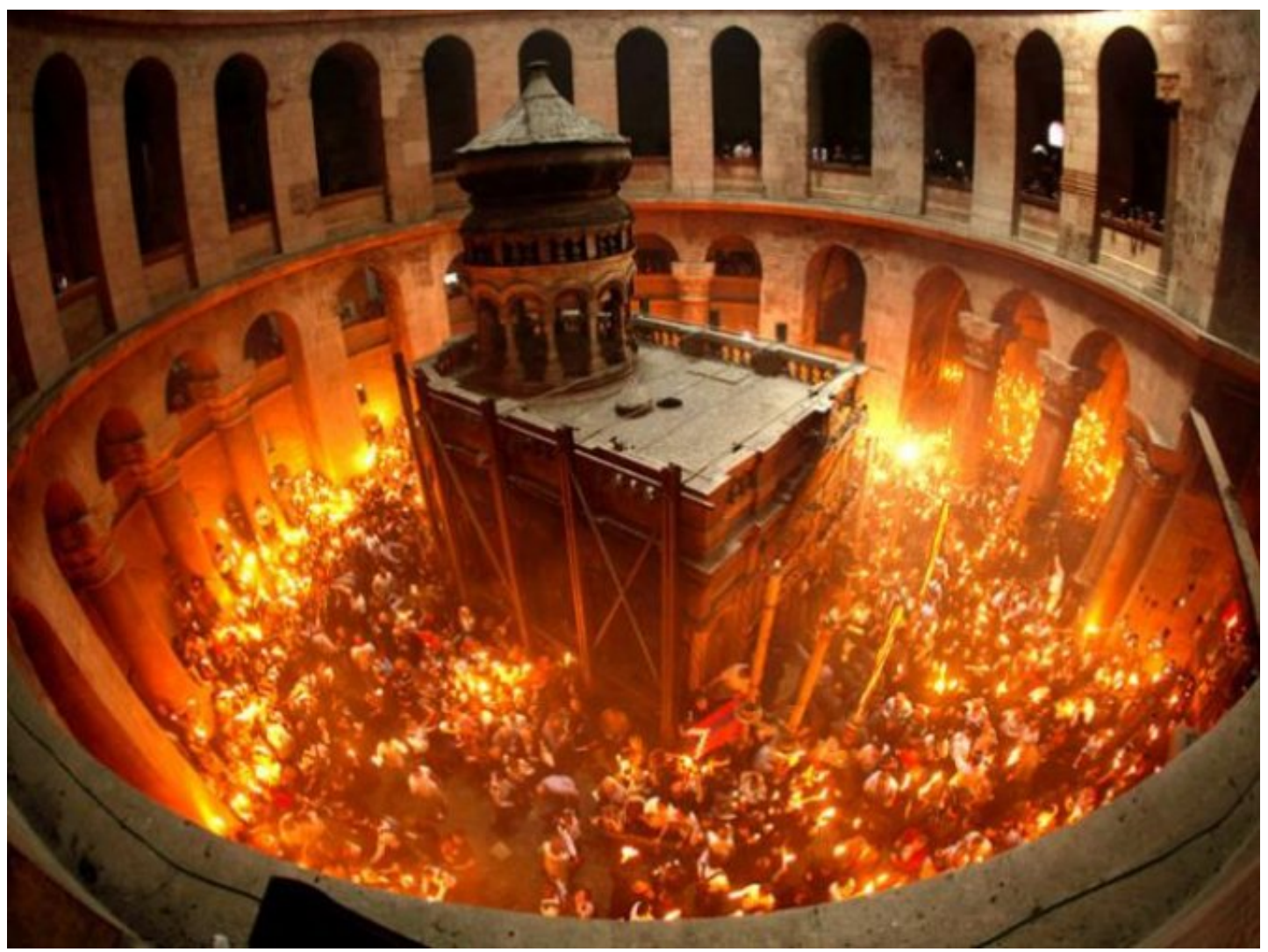

Foto: Wikipedia billeder.

Skønt man kan pege på en række lighedstræk mellem den omtalte Fourth of Julyparade og den ortodokse kirkes ildprocession, giver det god mening typologisk at skelne mellem dem. Den ene er orienteret mod et bestemt rumligt mål, Jesus' grav i Opstandelseskirken. Hertil drager man i procession, og når ildmiraklet er indtruffet, bevæger man sig på ny bort i procession, som så videreføres gennem utallige processioner, efterhånden som ilden når frem til de enkelte byer og kirker. Anderledes med 4. juli-paraden, som hverken har et herfra eller hertil, mens hvis hele mening netop består i selve paraderingen gennem byen. Man paraderer for tilskuerne ved at lade paraden drage gennem byens hovedfærdselsåre.

Den omtalte forskel kan også illustreres med et af de kunsthistorisk og arkæologisk mest berømte eksempler på en procession: panathenæerfesten, som den er afbilledet på Parthenon-templet på Akropolis. ${ }^{3}$ Skønt festen i dens klassiske skikkelse ofte forbindes med Peisistratos (600-527 f.v.t.), er det mere sandsynligt, at den stammer tilbage fra 566 f.v.t. og bygger på allerede eksisterende processionstraditi-

3 Der pågår i disse år en diskussion om, hvorvidt Parthenon-frisen faktisk forestiller panathenæerprocessionen eller om den snarere skal ses i sammenhæng med metoper og arkitravudsmykning som skildring af rivaliseringen og forligelsen mellem Erektheus og Athene som Athens mytiske guddommelige ophav, se diskussionen i Neils 2001, Boedeker \& Raaflaub 1998, og især Conelly 1996. Indtil videre holder jeg imidlertid fast i den klassiske forståelse af frisen som en ideel gengivelse af panathenæerprocessionen. Vi har først fra det femte årh. e.v.t. en fortolkning af frisen, så der er ikke hjælp at hente i den antikke verden selv. 
oner. Dens opgradering eller reform i 566 skal antagelig ses som et atheniensisk modsvar på andre religiøse fester som de nemiske, de pythiske og de isthmiske Lege, der afholdtes hvert andet eller fjerde år (Parker 1997, 89f.). Panathenæerfesten blev på denne måde et atheniensisk modsvar til andre lege, som truede Athens religiøst-kultiske, politiske, kulturelle og sociale stræben efter og krav på primat blandt de græske bystater. ${ }^{4}$

Panathenæerfesten blev afholdt som stor festival hvert fjerde år og som mindre fest de mellemliggende tre år. ${ }^{5}$ Den var placeret som indledning til det nye år på den 28. dag i måneden hekatombaion i juli, forløb over otte dage, og skulle ikke mindst rituelt og politisk markere Athen som samlende enhed for de græske bystater. Sammen med Synoikia som den anden af to festivaller skulle panathenæerfesten rituelt udtrykke kosmos' og ordens genoprettelse over for de to forudgående kaosfester Kronia og Skira i det forgangne års sidste måned (jf. Burkert 1983, 143-49; Bremmer 1999, 50). Panathenæerfestens procession var et indeksikalt udtryk for Athens overherredømme og for det sociale hierarki i Athen: "The procession is the supreme example in the Greek world of civic pageantry, of a society on display before itself and the rest of Greece" (Parker 1997, 91). Der var som ved enhver antik græsk festival forskellige kamp- og sportslege i forbindelse med den, altså såvel procession som agōn (egtl. forsamling og derefter om forsamling ved kamplege for så at bruges om kamp generelt; men anvendes i forskningen som almen betegnelse for den græske-hellenistiske konkurrence- og rivalliseringskultur). Der var musikog rapsodekonkurrencer, atletikkonkurrencer for såvel drenge og unge mænd som for mænd, konkurrencer med heste, spring til og fra krigsvogn, bådkonkurrence og det fakkelløb, som markerede indledningen til selve processionen (Neils 1992, 15f.).

Ganske som i den ortodokse festival for indvielsen af det nye kirkeårs ild og lys, indgik ild også i panathenæerfesten. Processionen og offeret indledtes ved daggry, hvor en løber bragte den nye ild fra Akademos' hellige Lund (dér hvor Platon senere skulle grundlægge sit Akademi) placeret på nord-vest-siden af byen uden for bymurene (jf. Aristophanes' Ran [dansk Frøerne] 1090-98 og Thukydid, ii 34, 5). Derfor var det også helt rimeligt, at vinderne af de panathenæiske lege fik en panathenæisk amfora med olivenolie fra Athenes hellige træer i Akademos' Lund. ${ }^{6}$

Centralt i festen stod processionen, som udgik fra Leokoreion ved Dipylonporten i Kerameikos (jf. Thukydid, vi 57) og videre ad den hellige vej frem over Agora og op mod Akropolisklippen forbi Nikebastionen over mod Parthenon, hvor Fidias' enorme Athene-statue stod i templets naos eller cella (dets centrale rum). Processionens mål var dog ikke Parthenon, men Erektheion på Parthenons nordside

4 Som både jeg selv og mange andre antikforskere har fremhævet gennem de sidste 25 år, var det, vi i dag betegner med tredje-ordens-kategorierne kultur og religion, i antikken sammenfaldende størrelser. Alt fra toiletbesøg, måltider, sport, teater, etc. var i større eller mindre grad del af det, vi med et etic-begreb kalder religion. Jeg følger her Weber og Durkheim i deres forståelse af, at religion netop først fra oplysningstiden bliver uddifferentieret som en selvstændig størrelse forskellig fra den øvrige kultur; se særligt Weber 1963, 546-54.

5 Dens opgradering i 566 f.v.t. bestod antagelig i, at man hvert fjerde år afholdt en særlig grandios version af festen.

6 Se udførligt Neils 1992. 
bygget oven på det ældre Athene-tempel, ødelagt i forbindelse med Den første persiske Krig i 480, ${ }^{7}$ hvor den noget mere simple og arkaiske statue af Athene polias ('byens Athene') blev iklædt en ny peplos med billede af gigantomachien (gudernes kamp mod titanerne) vævet ind i dragten (jf. Euripides, Hekuba 466-74, og Ifigenia $i$ Tauris 222-24). Den var vævet af Athens frie kvinder og blev båret frem af processionsskaren. ${ }^{8}$ Igen er der tale om en procession, hvor man skrider frem (pro-cedere) med et ganske bestemt rumligt mål for øje. Det fremgår også af det græske udtryk for procession pompe, som grundlæggende betyder at sende, ledsage eller eskortere (jf. verbet pempein). Det er naturligvis de hellige kar og andre rituelle artefakter, der tænkes på, og i sammenhæng med panathenæerprocessionen den hellige peplos til Athene.

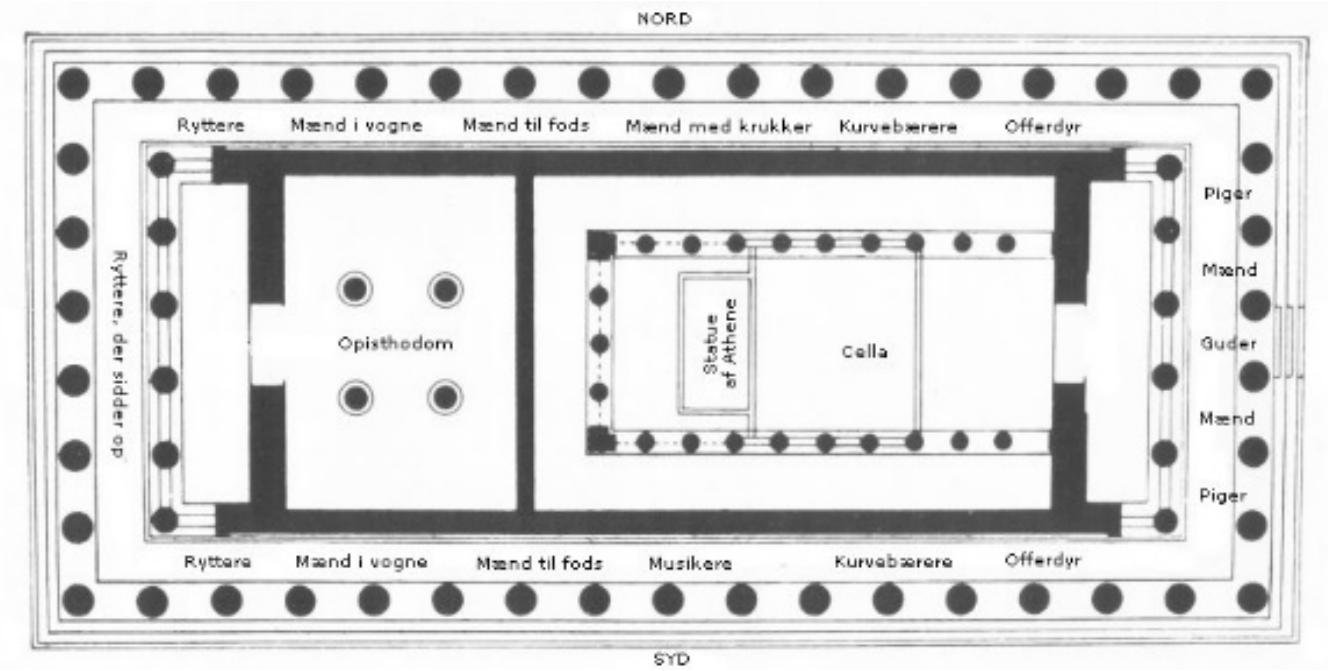

Parthenons grundplan med skildring af frisens motiver - efter Simon Laursen, Ribe Katedralskole.

Den 160 meter lange Parthenon-frise (hvoraf ca. 80 procent undslap Morosinis bombardement i 1687) er en ideologisk-politisk manifestation af atheniensisk religiøst og politisk herredømme over de andre græske bystater. ${ }^{9}$ Det var ikke mindst Peisistratos' fortjeneste at bane vejen for det atheniensiske overherredømme, der århundredet efter kulminerede under Perikles, som formåede at gøre Athen til primus inter pares i Det deliske Søforbund. Det var også under Perikles, at Akropolis undergik en betydelig ombygning, som blandt andet førte til det nuværende Parthenontempel, ombygningen af Nikebastionen og den storslåede og i allerhøjeste grad processionsegnede etablering af Propylæerne, gennem hvilken processionen bevægede sig op på selve Akropolisbjerget. Frisens ideologiske karakter gør, at den næppe kan tolkes

7 For den komplekse relation mellem Erechteus og Athene i panathenæersfesten rituelle gennemspilning, se Burkert 1983, 147-9. 157f.

8 Ved de store panathenaia hvert fjerde år blev dragten fragtet som sejl på det skib, der indgik i processionen, se Plutark, Demetrios' Liv 10, 5 og 12, 3, jf. Barber 1992.

9 Jeg kommer ikke her ind på diskussionen, hvordan frisen forholder sig til metoperne, som har gigantomachien, amazonekamp, kentaurkamp og endelig grækernes sejr over trojanerne som tema, ligesom jeg heller ikke drøfter den overordnede relation til arkitravernes udsmykning. Jeg er alene optaget af frisen som kilde til panathenæerprocessionen. 
som en tro gengivelse af den store procession i forbindelse med panathenæerfesten. Eksempelvis ved vi, at der selv ved de mindre panathenæerfester blev ofret over hundrede køer og får (Burkert 1983, 155, note 85), mens frisen kun indeholder nogle få repræsentative køer og får. Tilsvarende mangler frisen flere centrale persongrupper, som medvirkede i processionen. ${ }^{10}$ Det gælder fx metøkerpigerne, altså repræsentanter for den befolkningsgruppe, som ikke havde borgerskab i Athen, men boede der (jf. Aelian, Varia Historia, vi 1), repræsentanter for det deliske søforbund, slaver, det panathenæiske skib, og de militært væsentlige og berømmede hopliter. Ikke desto mindre giver frisen os et om end idealiseret så dog meget klart billede af, hvad en procession i antikken var.

Østsiden skildrer siddende guder i midterpartier omgivet af mænd på begge sider og på hver deres side unge kvinder. Syd- og nordsidens friser har stort set identiske motiver. Forrest offerdyr efterfulgt af kurvebærere med de forskellige rekvisitter til det efterfølgende offer. Hvor nordsiden har mænd med krukker, skildrer sydsiden de musikanter, som gennem musikledsagelse sørger for at løfte processionens effervescens. Begge friser følges så af gående mænd efterfulgt af mænd i stridsvogne og endelig ryttere en masse. Det er Athens militære, politiske og religiøst kultiske herredømme, som i den ikonale og derfor også idealiserede gengivelse lader processionen indeksikalt repræsentere og forherlige. Forholdet kom også til udtryk i, at Athens allierede og kolonier var forpligtet til at bringe offerdyr til processionen (Bremmer 1999, 40). Vestsiden og dermed templets bagside skildrer igen ryttere til hest. Frisen er på denne måde også en idealiseret skildring af græske køns- og seksualitetsidealer. Ingen modne kvinder i processessionen. Kun mænd, unge piger, præstinder og guder. Naturligvis har som sagt også andre taget del i processionen. Ud over de manglende elementer i selve processionen gælder det også tilskuerne. Der har sandsynligvis været lægter eller tribuner, hvor tilskuere har kunnet stå og følge processionen, ligesom børn og deres mødre som ved processioner i dag antagelig også har fulgt processionen på behørig afstand.

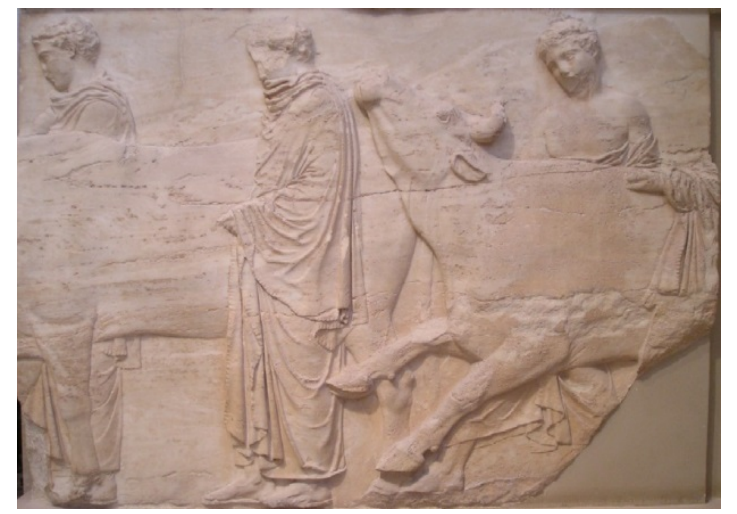

Offerdyr på Parthenons nordfrise blok nr. 2. Foto: Simon Laursen, Ribe Katedralskole.

10 For en problematisering af denne fortolkning af frisen, se Beard 2010, 133-48. 
Selve frisen skal læses med udgangspunkt i templets sydvestlige hjørne. Her deler processionen sig tilsyneladende i to parallelle skildringer. Rytterne, som i dag udgør 46 procent af den samlede bevarede frise, består af to rækker i ti rangordener, modsvarende de ti attiske stammer (Neils 2001, 132). Tavle nr. 42 på nordsiden og 89 på sydsiden gengiver antagelig ældre mandlige thallophoroi (bærere af Athenes hellige olivengren), som i kraft af deres smukke udseende var udvalgt til opgaven. Af musikanter kan man se både fløjte- og kitharspillere og muligvis trompetere, hvis trompeter på grund af ødelæggelse ikke længere kan ses. Der er vandbærere, $h y-$ driaphoroi, og skaphēphoroi, de, som bærer de fade med bikager og kager, som skal lokke offerdyrene frem mod offeralteret og sikre deres rituelle bifald til offeret - det er et gennemgående træk i antikke ofre, at offerdyrene selv skal markere deres billigelse af offeret. På østsiden kan man se en række af de unge piger og præstinder, som bærer rekvisitter til offeret, phiale (en lille krukke med parfume), oinochoai (vinkrukker), thymiastērion (røgelsesbrænder).

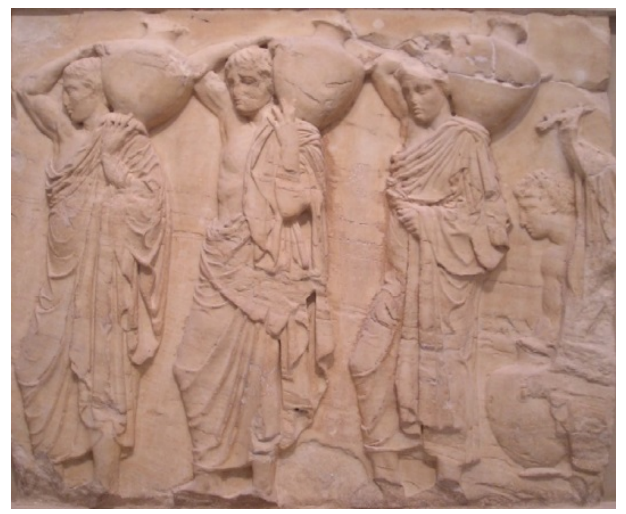

Vandbærere, nordsiden blok nr. 8. Foto: Simon Laursen, Ribe Katedralskole.

Her forlader jeg panathenæerprocessionen og foretager et drastisk spring frem i tid til nutidens Nordirland, til de såkaldte orangemarcher. Orangeparaderne er dog ikke begrænset til Nordirland. Hen over foråret og sommeren (fra april til august) går mænd i parader i Nordirland, Skotland, lejlighedsvis England og det øvrige Commonwealth som fx Australien og New Zealand. Der er kun ganske få steder tilbage i Irland, hvor man endnu vandrer og har lov til det. ${ }^{11}$ Paraderne når deres klimaks d. 12. juli, der markerer dagen for Prins William af Oranges sejr over James den Anden ved Slaget ved Boyne i 1690. Det var her katolicismen som officiel religion efter the Glorious Revolution i 1688 led endeligt skibbrud i England, Skotland og Nordirland. Undertiden marcheres også på Reformationsdagen d. 31. oktober, som ifølge traditionen var den dag, Luther i 1517 hængte sine 95 Teser op på kirkedøren til Allehelgens Kirke i Wittenberg.

I Nordirland holder orangemændene sig ikke tilbage for at vandre gennem katolske kvarterer, hvilket gennem tiden har udløst betydelig vold. Paraden er et show-

11 Den sidste orangemarch i Dublin går eksempelvis helt tilbage til 1937. Da der i dag kun er et fåtal af protestanter i selve Irland, er det kun i Rossnowlagh i County Donegal få kilometer fra grænsen til Nordirland, der afholdes orangemarch. 
off, og det går ikke stille for sig. Forrest går mænd med store orange bannere og vimpler. Derefter følger fløjte- og trommespillere og hyppigt også metalblæsere. Igen er der tale om en parade, hvor man vandrer gennem byen for at vise sit tilhørsforhold til protestantismen og indeksikalt markere sin overlegenhed og sejr over katolicismen. Men der er netop ikke tale om en procession med et bestemt geografisk mål for øje. I særligt en nordirsk, men også skotsk sammenhæng får marcherne også et stærkt politisk udtryk. Det er også det (i dag svundne) britiske imperiums suverænitet og overlegenhed over Irland og Skotland, som markeres gennem marchen. Intet under, at marcherne gennem tiden har været en betydelig anstødssten for katolikker og nationalister, som så også har måttet lide den tort, at marchen typisk har trådt netop deres byområder under fode.

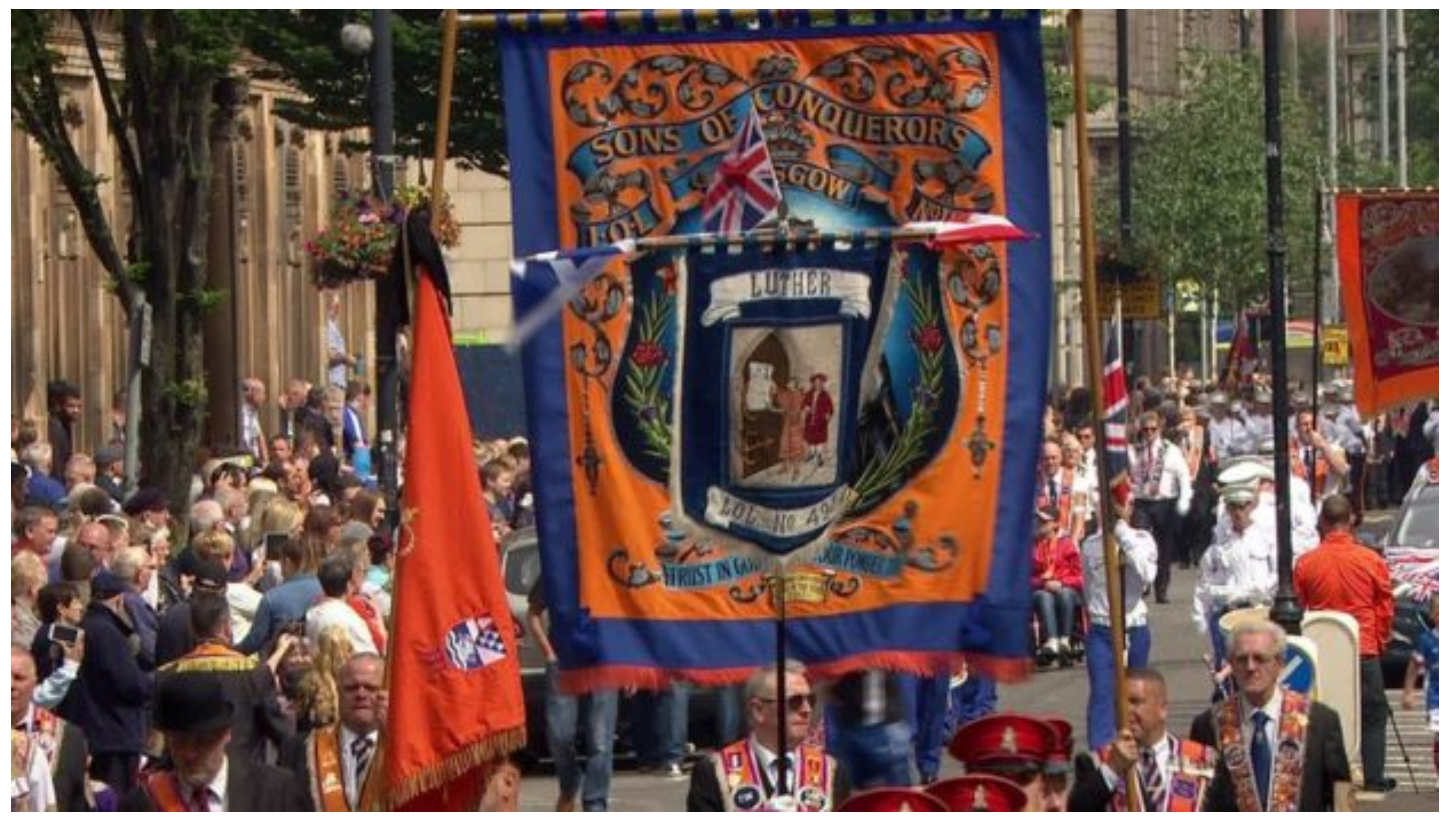

Foto: Wikipedia billeder.

I lyset af de forudgående eksempler vover jeg et øje og hævder i samklang med dette temanummers overordnede synspunkt, at marcher, parader og processioner samt, kunne man tilføje, i en sekulær kontekst demonstrationer har været et iøjnefaldende undervurderet fænomen i såvel religionsfænomenologien som religionshistorien. Hans J. Lundager Jensen har allerede i sin introduktion henvist til religionsvidenskabelige standardværker, hvor procession som selvstændig kategori glimrer ved sit totale fravær. Flere værker kunne føjes til, fx Brills nyeste skud på stammen, det prestigefyldte trebindsværk Vocabulary for the Study of Religion fra 2015. Det er dog ikke i denne sammenhæng, jeg risikerer mit øje, men i den videre argumentation. For jeg hævder yderligere i forlængelse af de forudgående eksempler, at det ikke alene er meningsfuldt at sondre mellem processioner og parader, men også at de religionshistorisk udspringer af forskellige kontekster og fortsat hører hjemme i forskellige sammenhænge. 


\section{Procession og parade: To forskellige religionshistoriske fænomener hjemhørende i forskellige religionstyper}

Både paraden og processionen er en magtdemonstration. Den er et indeksikalt udtryk for fællesskabet samlet om dets grundlæggende værdier. Nogle har skilt sig ud som dem, der marcherer. Men alle er del af gruppen, hvad enten man ser på eller selv paraderer eller procederer, medmindre man som i tilfældet med Orangemarcherne bruger paraderne til at udstille forskellen mellem in- og out-gruppe. Min påstand er, at paraden har en betydelig længere historie bag sig end processionen. Synkroniseret adfærd kender vi overalt i dyreriget, fra fugle over delfiner til aber (se særligt Sumpter 2010, 101-50). Det er en af de biologisk stærkeste måder at markere og etablere sammenhold på. Jeg hævder nu, at paraden netop med baggrund i sammenlignelige fænomener i dyreverdenen skal ses i tæt sammenhæng med tidlige jæger-samleres triumferende tilbagevenden fra jagt med byttedyr og i afskridtning eller paradering af ens territorium. Det er i den oprindelige kontekst et markant udtryk for indeksikal triumfalisme, maskulinitet og sejrsrus over den skaffede føde. Det er imidlertid også det, der tilføjer paraden og marchen dens negative aspekter.

Personligt har jeg svært ved at se på fodboldfans paraderen gennem gågaden $i$ Aarhus på vej mod stadion i samlet trop. Der er ikke langt fra gruppeeferverscens til vold og tilfældig lynchning. Jeg husker fortsat med gru, hvordan jeg som et lidt større barn var med mine bedsteforældre og fader i London. Et af de mindre fodboldhold, Bristol Rovers, var ved en fodboldkamp spillet i London rykket op fra fjerde til tredje division. Fansene samlede sig på Trafalgar Square under jubel, larm og gruppedans. Vi stod på behørig afstand og så på. En tilfældig nydelig påklædt yngre sort mand kom også forbi. Pludselig kastede hoben sig over ham og under stor jubel smed de ham i fontænen. Det gjorde et uudsletteligt indtryk på mig. Jeg kan endnu huske mandens rædselsslagne blik. Ingen hjalp ham. Det var den gemene masses tilfældige sejrsjubel udtrykt i vilkårlig vold.

Tilbage til paraden og marchen. Jeg hævder altså, at paraden som fænomen hører de tidligste former for religion til, mens processionen omvendt forudsætter de tidligste former for helligdomme, vi kender, ved overgangen fra jæger-samler-kulturer til tidlig agerbrug. Jeg tænker på sådan noget som Göbekli Tepe fra ca. 10.000 f.v.t. ${ }^{12}$ eller Çatalhöyük fra ca. 7.000-5.700 f.v.t., hvor vi finder de tidligste tempelkomplekser. Det kan jeg imidlertid ikke sige så meget om, fordi vi i modsætning til panathenæer- og Parthenon-eksemplet, hvor vi også har talrige skriftlige kilder, kun her i beskedent omfang kender til deres præcise brug ud over, hvad de arkæologiske levn tillader os at rekonstruere - og som bekendt giver det ikke rigtig mulighed for at gengive fortidige processioner. Vi ved kun lidt om, hvad der er foregået ved disse helligdomme. Jeg er mere sikker, når vi ser på fremkomsten af de tidligste og yder-

12 Renfrew $(2009,90)$ daterer Göbekle Tepe til 9.000 f.v.t. og pointerer med henvisning til Schmidt 2006, at helligdommen under alle omstændigheder går forud for domesticerede planter og dyr. 
ligere mere komplekse former for by-religion - det, der i Bellahs typologi betegnes arkaiske religioner. ${ }^{13}$

Jeg har først og fremmest de store og komplekse byreligioner for øje. Jeg tænker på mesopotamisk religion, babylonsk, ægyptisk, græsk, etc. Alle har de, som vi har set det $\mathrm{i}$ forbindelse med min drøftelse af panathenæerfesten, tempelarkitekturen og offerinstitutionen som helt afgørende omdrejningspunkt og symbolsk fokus for religionen. Det er muligvis ikke noget stort skridt at lade sejrsparaden træde i baggrunden til fordel for processionen frem mod templet; men der er ikke desto mindre en afgørende forskel. Processionen har en fremtrædende rolle i alle de store klassiske by-religioner. Vi har allerede set på panathenæerfesten; men også babylonsk og ægyptisk religion havde deres store og berømte processioner. I Babylon var det akitu- eller akitum-festen som en forårsfestival, der strakte sig over 12 dage, med genkaldelse af Marduks sejr over kaosuhyret Tiamat (se udførligt van der Toorn 1990). På festens niende dag spillede en procession en vigtig rolle. I Ægypten var det fx Opet-festen i Theben, hvor den guddommelige triade Amun, Mut og gudebarnet Khonsu blev transporteret i særlig processionsbåd både til lands og til vands fra Amun-Re-templet i Karnak på østsiden af Nilen til det tilsvarende tempel for Amun i Luxor (Theben) tilsvarende placeret på Nilens østside, hvorpå de igen blev ført tilbage (jf. Smith 2017, 491). Også her indgik bevægelsen fra kaos til kosmos som centralt element i ritualet, for Opet-festen faldt det sammen med Nilens oversvømmelse i månederne Paophi og Hathor. Det var gudens Ka, kraft eller sjæl, som på denne måde blev fornyet.

\section{Parader og processioner: et kort kultur- og religionshistorisk vue}

Jeg hævder altså, at parader udgjorde et centralt element i jæger-samler-religion, og at processioner tilsvarende i stigende grad kom til at udgøre et betydningsfuldt fænomen i komplekse agrarreligioner og i særdeleshed i tidlige og komplekse byreligioner. Men hvordan ser det ud, når vi bevæger os frem mod tidlige kosmos- og yderlige mod komplekse kosmosreligioner? - det der i Bellahs typologi betegnes aksetidsreligioner.

Jeg har i andre sammenhænge udfoldet min grundlæggende forståelse af tidlige kosmos- og komplekse kosmosreligioner og fremhævet i alt 12 træk som karakteristiske for dem (2017a-c og Turner et al. 2017). Her vil jeg nøjes med at hæfte mig ved nogle enkelte af de elementer, som jeg opfatter som grundlæggende for den religionstype, når det gælder spørgsmålet om processioner og parader.

Det er klart, at en religionsform, som bygger på en grundlæggende erkendelsesfigur, der ikke alene vægter det himmelske på bekostning af det jordiske, men også

13 Uden i øvrigt at anfægte genialiteten i Bellahs arbejder (jeg er fortsat en stor beundrer og afgørende inspireret af Bellah) tager jeg af forskellige grunde i dag afstand fra selve terminologien. Både fordi den låser et komparativt aspekt til et eurasiastisk perspektiv, og fordi den ikke i tilstrækkelig grad gør de socio-materielle forudsætninger klart for tilblivelsen af nye former for religion, samt at den ophøjer en bestemt type kultur/religion (aksialreligion) på bekostning af andre. 
pointerer den kategoriale forskel mellem det jordiske og det himmelske, må nedtone processioner og parader. Fordi de i udstrakt grad repræsenterer et indeksikalt udtryk for magt, hierarki, pragt, status og kosmosbejaelse, må de afvises. Man hylder ikke den jordiske verdens pragt og magt, når den enten forstås som en kun ringe afglans af eller en direkte modsætning til den himmelske verdens værdi- og symbolsæt. Parallelt med værditilskrivningen på den lodrette akse (himmel :: jord) finder der en betydningsinvestering sted på dybdeaksen, hvor det indre fremhæves på bekostning af det ydre: Sjælen fanget i legemets fængsel. Også her kommer procession og parade med deres vægtning af pomp and circumstance til kort. I et større kommende arbejde hævder jeg, at der i de tidlige kosmosreligioner tillige kan ses en tendens i retning af øget individualisering. Jeg taler selvsagt ikke om 'menneskets udtræden af dets selvforskyldte umyndiggørelse' eller om en forestilling om det enkelte individs autonomi i et omfang, som først hører oplysningstidens tænkning til. Men jeg hævder, at det er mere meningsfuldt at søge denne begyndelse med tilblivelsen af tidlige kosmosreligioner. ${ }^{14}$ Overhovedet det forhold, at der i de tidlige kosmosreligioner indgår en central forestilling om, at hele menneskelivet skal forstås som et langt træningsprogram (askēsis) for den enkelte til bekæmpelse af begær (epithumia) og lidenskaber (pathē), ${ }^{15}$ eller som Pierre Hadot har formuleret det, filosofien som en livsvej (une manière de vivre, se fx 1995, 91-352; 2001, 91-141; 2002, 289304), peger i retning af øget individualisering eller $i$ al fald en større anerkendelse af den enkelte i forhold til hoben, samfundet eller kollektivet. Men hvad har det nu med parader og processioner at gøre?

Ganske meget, hævder jeg. Der ligger i kosmosreligionerne et ubehag over for alle tidligere religionsformers (og derfor i særdeleshed de komplekse by- eller arkaiske religioner) gruppebekræftelse. Den enkelte opgiver sit særpræg for at blive en del af gruppen eller fællesskabet. Just det, som i den durkheimske religions- og kulturforståelse er helt grundlæggende for al religion. I den forstand kan man også med en vis ret hævde, at der i kosmosreligionerne ligger en religionskritik indbygget, selvom den ikke, skønt det ofte er gjort, må identificeres med senere former for religionskritik som f.eks. Feuerbachs projektionstese. Tilhørsforholdet til gruppen på bekostning af selv'et, som det her formuleres. I dag ville vi sige jeg'et eller individet. Netop denne udviskning af selv'et, som finder sted i forbindelse med processioner og parader, hvor selv'et giver afkald på 'individualiteten' for at blive en del af gruppen og dens overordnede værdier og symboler, gør aksial- eller kosmosreligionerne op med. Derfor får de et anstrengt forhold til ethvert kultisk element, som tenderer mod en for kraftig udviskning af selv'et til fordel for kollektivet, ligesom

14 Over for et stort anlagt forskningsprojekt omkring individ og individualisering ved Max Weber Advanced Institute i Erfurt, der forsøger at tidsfæste og lokalisere tilblivelsen af en individ- og individualiseringstanke til århundrederne omkring vor tidsregnings begyndelse til Rom, søger jeg at udvikle en typologi, som sætter os i stand til at skelne mellem forskellige former for selv-forståelse, individualitet og individualisering med vægt lagt på overgangen fra komplekse byreligioner til tidlige kosmosreligioner, se Petersen 2018.

15 Se i denne sammenhæng Poplutz' fremragende afhandling fra 2004, hvor alle de væsentligste kilder, der anvender sports- og træningsmetaforikken, er anført, uden at hun dog går ind i den mere grundlæggende åndshistoriske drøftelse. 
de også og tæt forbundet med det første punkt reagerer på den verdensbejaelse, som ligger i både processionen og særligt i paraden. Eller sagt på anden vis: Parader og processioner er i udgangspunktet ikke et konstitutivt træk ved kosmosreligionerne.

Som det imidlertid er velkendt fra evolutionstænkningen, såvel den biologisk som den specifikt kulturelle, gælder det maksime, som også Robert Bellah gjorde til en hovedpointe i sin kulturevolutionære tænkning om religion og kultur: "Nothing is ever lost" (2011a; 2011b, xviii. 65). Derfor vil jeg slutte dette afsnit med to eksempler på processionstænkning i den kosmosreligiøse kontekst. Her kan vi på den ene side konstatere, at man tilsyneladende ikke kan være processions- og parademetaforikken foruden, mens man på den anden side har været nødt til at omtolke det på en måde, så det tilgodeser det 'aksiale ubehag' over for netop dette fænomen. Eksemplerne er begge hentet fra tidlig Kristusreligion; men jeg hævder uden her at kunne dokumentere det gennem inddragelse af eksempler uden for formativ Kristusreligion, at de er symptomatiske for aksialt ubehag over for processionens og paradens verdensbejaelse. Først Paulus og dernæst Matthæusevangeliet.

Jeg begynder i 2 Kor. skrevet en gang i begyndelsen af 50'erne. Paulus skriver til en menighed, som han har betydelige problemer med. 1 Kor. var et forsøg på at løse disse problemer; men tingene har udviklet sig til det værre. Paulus har valgt - med god grund - at holde sig på afstand af menigheden for ikke at skabe yderligere problemer. I stedet for sender han dem et nyt brev, in casu 2 Kor.; men det har selvsagt ikke gjort problemerne mindre, fordi menigheden netop anklager ham for blandt andet at ville sidde på afstand og gennem skriftlig kommunikation forsøge at styre gruppen og løse problemerne. I virkeligheden er han, ræsonerer de, en bangebuks, som ikke tør at møde op in persona og tage imod de tæsk, han fortjener. Nogle latterliggør også hans apostolat og selvforståelse, ligesom de i forbindelse med kollekten til Jerusalem anklager ham for at have stukket penge til side. Brevet er et forsøg på at intervenere og skabe fred og forsoning, indtil han på ny kan komme til den menighed, som han kun en gang tidligere har besøgt, nemlig ved sin grundlæggelse af den.

Derfor formulerer han også sin brevtese meget forsigtigt, idet han her får pointeret de to centrale aspekter, som bestemmer brevsituationen: Selvforsvar for Paulus over for de anklager, der er rettet mod ham, og et politisk indgreb, der skal bane vejen for et fornyet og godt forhold til menigheden. Kort sagt er brevet både det, man i antik retorisk sammenhæng kalder en apologi, og et deliberativt (genus sumbouleutikon) brev formuleret med henblik på igen at skabe gruppesolidaritet og social kohærens: "For vor ros er selve dette, vidnesbyrdet om vor samvittighed, at vi i oprigtighed og renfærdighed over for Gud og ikke ved kødelig visdom, men ved Guds nåde har vandret i verden og så meget desto mere over for Jer. Vi skriver ikke andre ting til Jer, end hvad I selv kan læse og erkende. Jeg håber, I vil erkende det til fuldkommenhed, ligesom I også har erkendt os, delvist, at vi er Jeres ros, ligesom også I er vor på vor Herre Jesus' dag" (2 Kor 1, 12-14 - min oversættelse). Her er ikke meget at rafle om. Brevet er skrevet for at bibringe adressaterne en forståelse af Paulus, som han håber, de vil tilegne sig, men som de altså aktuelt ikke har. 
I kap. 2 beskriver han og forholder sig til nogle af de forhold, som har givet anledning til problemerne mellem menigheden (betydelige dele af, men ikke nødvendigvis alle) og ham selv. Det gælder problemerne med den såkaldte sexsynder fra 1 Kor 5, og det vedrører Paulus' ændrede rejseplaner og dermed hans udeblevne tilbagekomst til den menighed, han selv har grundlagt. I afsnittet 2, 14-17, første del af brevets beviskompleks (probatio, der strækker sig frem til 7:16) gentager han dels pointen fra brevtesen og dermed selve formålet med brevet, dels placerer han drøftelsen i en større kosmoteologisk ramme. Det er i denne sammenhæng, processionstemaet er centralt og interessant for min problemstilling.

Som en marionetfigur er al Paulus' gøren og færden styret af Gud i et kosmisk teater: Himmel og jord som 'Weltbühne' for Paulus: “Gud ske tak, som overalt fører os i procession (thriambeuonti) i Kristus og gennem os gør sin erkendelses lugt tydeligt klar (phanerounti) på ethvert sted. For vi er Kristus' vellugt over for Gud blandt dem, som frelses, og dem, som går til grunde. For de første er det en stank (osmē) fra død til død. For de andre en lugt (osmē) fra liv til liv. Og hvem er duelig til dette? For vi er ikke som de mange, som sælger Guds ord (logos) som en kræmmervare (hoi de kapēleuontes), men som af renfærdighed (eks eilikreineias, jf. 1, 12) taler vi fra Gud over for Gud i Kristus" (min oversættelse). Hvad er meningen?

Af den officielle danske oversættelse kunne man få det indtryk, at der er tale om noget positivt prangende: "Men Gud ske tak, som altid fører os med i Kristi triumftog og overalt lader os udsprede kundskaben om ham som en duft..." Denne oversættelse er en blandt flere andre direkte fejlagtige og antagelig i sidste instans dogmatisk begrundede forkerte oversættelser. Den præsenterer den diametralt modsatte betydning af den græske tekst. Desværre. ${ }^{16}$ Paulus' tænkning er bastant aksial. Det er den, om man vil, platonske spænding mellem hulen og det himmelske lys, der her sættes på spidsen $\mathrm{i}$ to metaforer forbundne gennem processionstemaet. En krigsmetafor og en olfaktorisk metafor knyttet til lugtesansen. Men baggrunden for at forstå afsnittet er den græsk-romersk filosofiske forestilling om filosoffen eller den vise (ho sophos) som den, der er i stand til at modstå lidelser. ${ }^{17}$ Den stoiske filosof Epiktet formulerer det meget tydeligt: “Det er lidelser, som gør mænd til mænd (hai peristaseis eisin hai tous andras deiknuousai, I xxiv 1). En anden stoiker, Musonius Rufus, pointerer: “Vi bruger træning (askēseōs) til begge (dvs. både sjæl og legeme $\mathrm{AKP}$ ), når vi forvænner (sunethizomenōn hèmōn) os til kulde, hede, tørst, sult, knaphed på mad (dvs. ved rationer givet til soldater - AKP), hårdhed på lejet, undvigelse af lyster (apochē tōn hèdeōn) og udholdenhed i lidelser. For gennem disse og andre sådanne styrkes legemet og formår at forholde sig upåvirket af lidenskab (dus-

16 Jeg nævner i flæng andre arbejder, hvor jeg påpeger graverende oversættelser af ord og passager i Bibelen, som i sidste instans antagelig skyldes, at dogmatisk-teologiske hensyn vægtes over filologisk viden og akkuratesse, se Petersen 2008, 47-52; 2017c. Derfor er jeg i stigende grad tilhænger af, at der udarbejdes en egentlig videnskabelig funderet og understøttet oversættelse af Bibelen.

17 Der har de seneste år været skrevet megen litteratur om dette emne, men de klareste og efter min mening mest fortrinlige værker er i denne sammenhæng Fitzgerald 1988 og Ebner 1991. Her bygger jeg i høj grad på de ting, jeg ikke mindst har lært hos Fitzgerald og Ebner. Se særligt Fitzgerald $1988,160-65$. 
pathes), stærkt og klar til enhver gerning. Sjælen styrkes også, idet den trænes (gumnazomenē) i udholdenhed for at opnå mod og i undvigelse af lyster (apochē tōn hēdeōn) for at opnå besindighed" (VI Peri Askēseōs p. 25, 6-14 Hense 1905).

Det er i sådanne tanker, vi finder baggrunden for den paulinske forståelse. Det græske ord, thriambeuein, bruges aldrig nogensinde i betydningen 'at føre i triumftog', men altid som 'at blive ført i triumftog'. Det er altså som krigsfange og ikke sejrherre, Paulus fremstiller sig selv i et guddommelig kosmisk teater. Det sker 'altid' (pantote) og 'overalt' (en panti topō). Paulus udsender i denne sammenhæng en lugt svarende til processionernes røgelsesbærere; men modsat dem er den paulinske duft af en noget anderledes karat. Den er en ligstank af død og til død. Eller som da han længere fremme i brevet genoptager metaforikken: "Overalt bærer vi i vort legeme rundt på Jesus' dødelse (nekrōsis - i betydningen et lig, der er i gang med at undergå en forrådnelsesproces)" (4,10a). Her er ikke megen pomp eller pragt. Det er de ydmygedes parade, hvor de udstilles i al deres afmægtighed og svaghed.

Helt i kosmosreligionernes ånd foretager Paulus imidlertid en drastisk værdiomkalfatring gennem påstanden om, at den himmelske verdens duft i denne verden kommer til udtryk under modsat fortegn, eller bliver til noget kontrært. Ikke som liflig vellugt, men som modbydelig dødsstank. Kun de, som frelses, begriber det imidlertid; mens lugten for dem, som fortabes, er, hvad den giver sig ud for at være, nemlig en ligstank. Det kræver en særlig erkendelse at forstå, at ligstanken udgår fra den himmelske verden. Netop fordi der er en radikal forskel mellem denne og den anden verden, må den anden verden i denne verden komme til udtryk i et modsætningsforhold til denne verdens værdier og skattede fænomener. Ikke røgelse, men råd! Paulus stiller så spørgsmålet, hvem der i virkeligheden er duelig til dette $(2$, 16c). Den underforståede tanke er, at netop kun han selv er den rette mediator mellem Gud, Kristus og korintherne. I afsnittets afsluttende vers får han underforstået og foregribende spiddet de forkyndere, som han senere i brevet skildrer dels som 'superapostle', dels som sine rivaler (10-13, se særligt 10, 12-18), gennem påstanden om, at han selv og hans medarbejdere ikke er som sofister: "de sælger ikke Guds ord som en kræmmervare" (jf. Platon, Protagoras 312e-315b og Sofisten 221c-224e). Tanken er selvsagt, at de 'andre' forkyndere er sådanne sofister, som søger at udbytte korintherne.

Summa summarum: Paulus har brugt en processionsmetafor, som hører romerske hærførerprocessioner til. En succesfuld general eller kejser vendte tilbage til Rom og under pomp og pragt blev der afholdt en procession, hvorunder også de slagne fik lov at blive udstillet som skammens objekter, mennesker, som var bukket under for romersk overmagt. Det kan måske godt ligne paraden, men processionen, som hører den arkaiske eller by-religionen til, overtrumfer paradeelementet. For sejrstoget bevægede sig mod Capitol mod Jupiter-templet, hvor sejrsherren, stående på triumfvogn og iført laurbærkrone og den guldbroderede, purpurfarvede toga picta som et indeksikalt udtryk for hans gudelignende status, ofrede til guden, Jupiter Capitolinus. Det var på mange måder parallelt til panathenæerprocessionen. Sejrsprocessionen tog sit udgangspunkt på vest-siden af Tiberen på den sydlige del af Marsmarken - uden for det hellige byområde, pomerium - et eller andet sted mel- 
lem Marcellus-Teateret og Pompejus' søjlegange. Den bevægede sig gennem porta triumphalis over Forum Boarium (oksemarkedet) mod Circus Maximus for derpå at drage videre mod og ad den hellige vej, Sacra Via, over Forum og op mod Capitol (se udførligt Versnel 1970 og Beard 2007). ${ }^{18}$ Det er dette billede, Paulus drejer 180 grader gennem påstanden om, at netop de slagne og udstillede er identiske med Guds velduft. Just de udgør den gruppe, som skal frelses. Meget mere bombastisk aksialt kan det ikke blive. Eller som Nietzsche formulerede det i den berømte fortale til Jenseits von Gut und Böse. Vorspiel einer Philosophie der Zukunft fra 1886: "Denn Christentum ist Platonismus fürs 'Volk'” (Nietzsche 1985, 156).

Jesus' indtog i Jerusalem palmesøndag skildrer også en procession, men de færreste har forstået tekstens egentlige pointe i dens matthæanske version. Her drejer det sig ikke så meget om messiasfiguren, der som i Markus kommer ridende ind til Jerusalem i al ydmyghed. Det er snarere et Dario Fo'sk paradenummer med en klovn, som kommer ridende ind til byen fulgt af sin pjaltehær. Til forskel fra Markus er der i Matthæus ingen tvivl om, at Jesus kommer ridende ind på to æsler: "De kom med æslet og føllet og lagde deres kapper på dem, og han satte sig på dem" (epanō autōn, Matt 21,7). Jeg vil ikke gøre mere ud af denne tekst, men blot pointere, at den er en narrativ iscenesættelse af den samme grundlæggende aksiale epistemologi, som vi også mødte hos Paulus. Klovnen er kejser, mens kejseren er klovn. Her tages der i narrativ form et blandt mange andre livtag med det politiske system, som kommer til kort målt med den himmelske verdens alen. Jesus' herredømme er netop af en anden verden, og den anden verden står i et diametralt modsætningsforhold til denne verden. Derfor kan den anden verdens værdier og antihierarkisering kun udfoldes under modsat fortegn. Soldaterne er disciplenes pjaltehær, og kejseren er cirkusartisten Jesus ridende på to æsler.

Processionen bliver også her til en parodi på en procession, en antiprocession, som Victor Turner ville kalde det. Ved at ride ind i magtens centrum afmonteres magten, men som hos Paulus kun for den, som har øjne at se med og øren at høre med. Det kræver en særlig form for erkendelse, som har blik for den aksiale vending. Dermed er jeg nået vejs ende i dette lident vue over den postarkaiske eller post-by-religioner form for religion. Jeg er mig fuldt bevidst, at mine eksempler har været hentet fra jødedommen, fra tidlig Kristusreligion. Mit synspunkt er, at hvad jeg her har fremhævet gennem to eksempler, er symptomatisk for kosmosreligionernes eller de aksiale religioners relation til den arkaiske religionsform eller byreligionen. Men som jeg også har understreget, gælder det her, at: Nothing is ever lost. Med kristendommens videre udvikling og ikke mindst det punkt, hvorfra den gik fra at være en form for jødedom (tidlig Kristusreligion) til at blive en i forhold til jødedommen uafhængig og selvstændig religion (kristendom), var vejen også banet for en rearkaisering af religionen og dermed for forholdet til processioner. Da Kristusreligionen blev smedet $\mathrm{i}$ hymens lænker med romermagten i løbet af det fjerde århundrede, begyndte tempelreligionen på ny at vinde indpas. Kirkebygninger fik arkitektonisk en umiskendelig lighed med de gamle tempelbyggerier og processio-

18 For rekonstruktion af selve ruten, se særligt Beard 2007, 92-105. 
nerne kunne vende tilbage, sådan som vi kender det fra fx Kyril af Jerusalems Mystagogiske dåbskatekeser fra netop det fjerde århundrede e.v.t. Men det er en anden historie.

Her forlader jeg det religionshistoriske vue og stiller på ny spørgsmålet om parader og processioner, men nu i særlig grad fra et ritualteoretisk og især biokulturelt evolutionært perspektiv. Hvorfor har de tilsyneladende en sådan grad af appel, så åbenbart heller ikke kosmosreligionerne kunne være dem foruden, men måtte indoptage dem igen efter i en lang periode at have forsaget dem i kraft af deres individualitetsudviskning og gruppebekræftelse?

\section{Fra parade og procession til eksercits, bonding og københavnske brandmænd}

Fra forslaget om typologisk at sondre mellem procession og parade, min beslægtede tanke om, at de som fænomener hører hjemme i forskellige kultur- og religionshistoriske kontekster, og endelig drøftelsen af parade og procession i en kosmosreligiøs kontekst bevæger jeg mig nu frem til artiklens anden del. Her vil jeg drage nytte af en ritualteoretisk tradition, som hverken i den danske eller internationale i al fald religionsvidenskabelige og antropologiske ritualdiskussion har fået synderlig opmærksomhed. En række navnlig sociologisk inspirererede forskere har gennem en årrække været optaget af synkronisering og udvekslingsritualer hos mennesker. Jeg er selv blevet opmærksom på en tidligere amerikansk professor i militærhistorie ved Chicago University, William McNeill, hvis værnepligt blev aftjent i forbindelse med Vietnamkrigen. McNeill kom ikke selv til Vietnam, men han nåede at aftjene værnepligt ved den amerikanske hærs militærakademi ved West Point eller slet og ret USMA.

Han undrede sig dengang over, hvorfor de i al uendelighed skulle gå parade, doing the drill. Igen og igen blev de tvunget til eksercits, hvor de daglige parader tilsyneladende ingen ende ville tage. Mange år senere tog McNeill spørgsmålet op og nåede frem til, at det faktisk giver uendelig god mening. Men først hans forundring:

What I remember now, years afterwards, is that I rather liked strutting around, and so, I feel sure, did most of my fellows (det er dog kun retrospektivt, at de tænker det på den måde - AKP). Marching aimlessly about on the drill field, swaggering in conformity with prescribed military postures, conscious only of keeping in step so as to make the next move correctly and in time somehow felt good. Words are inadequate to describe the emotion aroused by the prolonged movement in unison that drilling involved. A sense of pervasive well-being is what I recall; more specifically; a sort of swelling out, becoming bigger than life, thanks to participation in ritual $(1995,2)$.

Så kan beskrivelsen af oplevelsen vist ikke blive mere durkheimsk: jeg'et der udviskes i en effervescent erfaring af kollektivets altomfattende trans-mundane karakter. McNeill understreger et andet sted denne durkheimske karakter gennem en soldats tilbageblik. Først gør han opmærksom på det lettere paradoksale fænomen, at evnen 
til at marchere havde en vigtig militær betydning på slagmarken frem til 1840, men herefter mistede det på grund af indførelsen af mere udviklet artilleri sin funktion. Ikke desto mindre spiller det fortsat en vigtig rolle i militær uddannelse; men hvad er formålet så? Det skaber ikke alene social sammenhængskraft i gruppen, men giver også deltagerne en følelse af, at forskellen mellem 'jeg' og 'vi' udviskes:

Many veterans who are honest with themselves will admit, I believe, that the experience of communal effort in battle, even under the altered conditions of modern war, has been the high point of their lives... Their "I" passes insensibly into a "we," "my" becomes "our," and individual fate loses its central importance... I believe that it is nothing less than the assurance of immortality that makes self sacrifice at these moments so relatively easy... I may fall, but I do not die, for that which is real in me goes forward and lives on in the comrades for whom I gave up my life (McNeill 1995, 10).

McNeill taler ikke her om parade specifikt, men i stedet for om selve kampen. I McNeills forståelse gælder det imidlertid tilsvarende for march og dans, at de ligesom krig i kraft af de stærkt synkroniserede bevægelser skaber og opretholder sammenhold i gruppen. Der er en berømt passage i Les formes élémentaires de la vie religieuse, hvor Durkheim taler om soldaten, som falder i forsvaret for sit lands flag. Om ham gælder det, at han 'grundlæggende ikke tror, at han har ofret sig for et stykke stof. Det er den sociale forestilling, som i kraft af den uafviselige autoritet, der er indeholdt i den, har en virkning, som den individuelle tanke ikke kunne have' (2007, 341 - min oversættelse). Jeg samstemmer med Durkheim, men føjer også en vigtig korrigerende og samtidig korresponderende pointe til: Soldaten dør ikke for flag, fædreland eller den sociale tanke; men han dør for sin buddy, som han har tilbragt tiden i march og i skyttegrav sammen med. At det så samtidig må tage sig ud som et offer for den sociale tanke, har Durkheim fuldstændig ret i; men det er i kraft af den hormonalt etablerede forbundethed med kammeraterne, der ikke mindst er opnået gennem de fælles parader. ${ }^{19}$

Jeg har gennem et stykke tid været optaget af den amerikanske sociolog og ritualteoretiker Randall Collins, som lægger afgørende vægt på det, han kalder udvekslingsritualet som en slags minimalritual for at skabe social bonding og gruppekohærens. Collins er durkheimianer og lægger derfor afgørende vægt på følelsen som det centrale i ritualisering. Det er efter min mening også her, vi skal finde baggrunden for den sociale og rituelle betydning bag processioner og parader. Men lad mig begynde overvejelserne et noget andet sted, end vi er vant til.

Politiken havde maj 2016 en serie om kropsberøring. I en artikel af Elisabeth Astrup skrev hun om brandmændene i Hovedstadens Beredskab. Hun fortæller om, hvordan de møder tidligt ind og giver hinanden hånd enkeltvis. Der stod meget interessant at læse i artiklen, som jeg derfor også gengiver her i et fyldigt uddrag:

Hilseritualet, der har eksisteret gennem flere hundrede år blandt beredskabets ansatte

19 Ehrenreich $(2007,180-97)$, er inde på lignende tanker i sin drøftelse af militære parader som fx ved Nürnberg-Kongressen i $1934 \mathrm{og}$ i andre parallelle fascistoide iscenesættelser af parader. For de kollektivt synkroniserede hormonale udladninger, se Turner et al. 2017, 95f., og Nummenmaa et al. 2012; se også Thunberg \& Dimberg 1998. 
i hovedstaden, varer kun et øjeblik. Men betydningen er afgørende. "Det er vigtigt. For der er ingen af os, der ved, hvornår det slutter," forklarer 54-årige Per Rasmussen, der har været i korpset i 29 år. Han fortæller, at håndtrykket og udvekslingen af øjenkontakt blandt hovedstadens brandmænd er sådan en slags pant på, at man er parat til at være der for hinanden, når det gælder. "I gamle dage måtte man jo drikke alkohol på mange arbejdspladser - også her hos os. Så sad man oppe hele natten og tævede kort - nogle tabte, andre vandt. Og når så det blev morgen, gik man hver til sidst (sic!). Men når man mødte ind den efterfølgende vagt og gav hånd, var alt, hvad der lå bagude, glemt. Alt var væk. Med det håndtryk besegler man en overenskomst om, at $\mathrm{i}$ dag kan vi stole på hinanden", forklarer han. "Konkret betyder det, at hvis min makker brænder røven, så får jeg ham ud. Og hvis jeg brænder bagi, så stoler jeg på, at han får mig ud. Når man giver hånden til hinanden, mærker man en slags energi, der flyder mellem os. Det er respekten, der går begge veje". Per Rasmussen mistede på et tidspunkt en nær kollega. "Pludselig en dag faldt han gennem taget under en brand og blev slået ihjel. På sådan en dag er man glad for, at man har givet hånd om morgenen. Jeg var ikke selv på vagt med ham den dag, det skete, men de, der var og havde givet hånd, fik vist den respekt, vi har for hinanden, og som ligger i det håndtryk", siger han" (oprindelig tegnsætning bevaret).

Det er den samme form for nærhed og forbundethed, der indøves i forbindelse med den militære parade, og hvis betydning de tidligere henvisninger til McNeill understregede. I paraden og processionen udstrækkes den følelsesmæssige energi i det simple udvekslingsritual til den større gruppe gennem den kropslige nærhed og forbindelse mellem de deltagende.

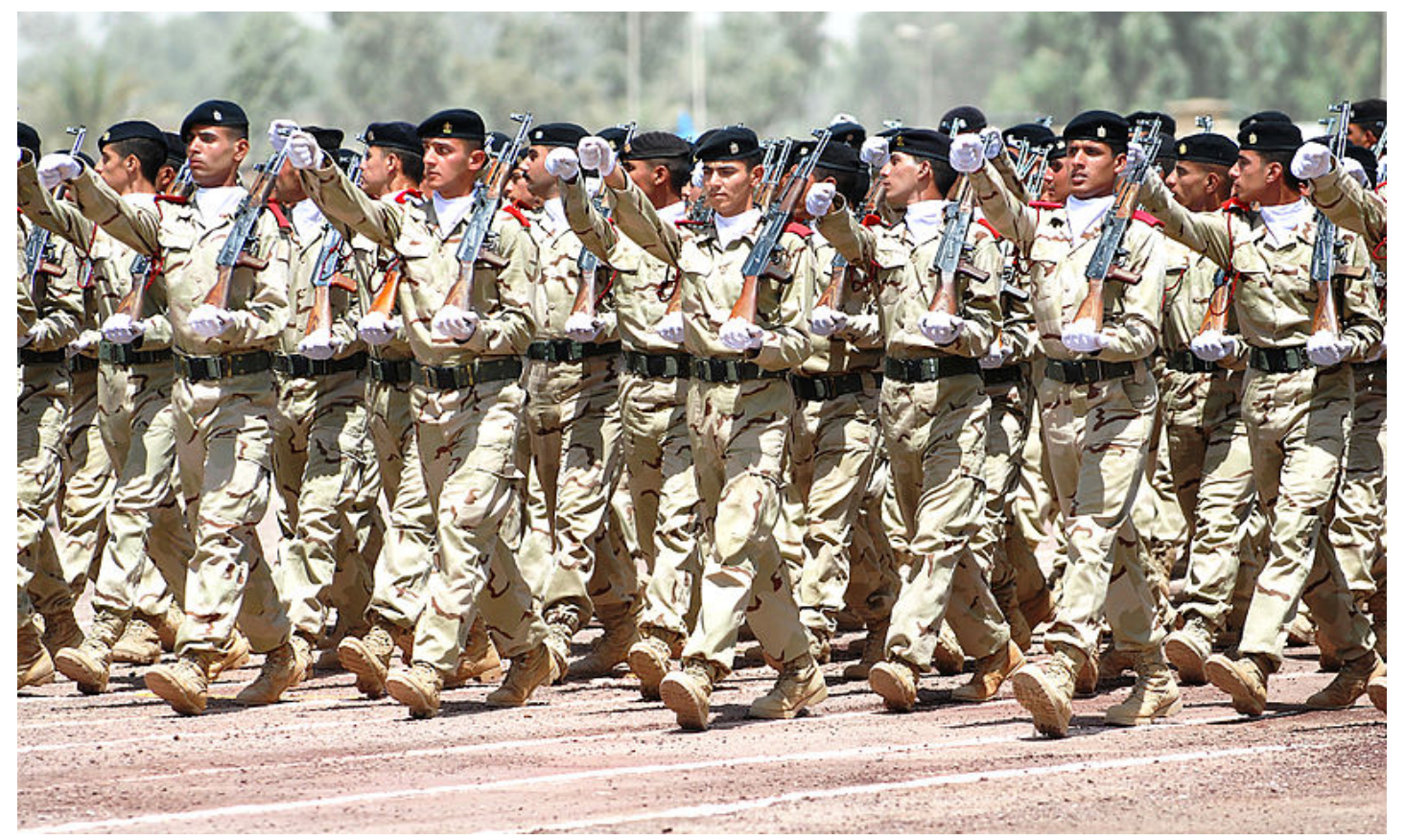

Foto: Wikimedia Commons, irakiske sikkerhedsstyrker Bagdad 30. juni 2009. 


\section{Parade og procession i dyreriget}

Hermed er jeg kommet til sidste del af mine overvejelser. Mit udgangspunkt er, sådan som jeg generelt tænker i dag om biologi, kultur og evolution, en tanke fra Darwins geniale pionerarbejde The Descent of Man, hvor han pointerer, at: 'Ikke desto mindre er forskellen i tænkning mellem mennesket (man) og mere udviklede dyr (higher animals), stor som den er, bestemt udtryk for en grads- og ikke en artforskel' (1936, 494 - min oversættelse).$^{20}$ Ideen er at man dels for at forstå, hvad der er på spil hos mennesket, må se til de øvrige dyr, dels at al biologi (og i min optik også kultur) må tænkes ud fra en tanke om evolution eller kontinuitet.

Findes der med andre ord noget hos andre dyr, som modsvarer den menneskelige tilbøjelighed til parader og processioner? Vi søger ofte hos vore nærmeste fæller blandt menneskeaberne, bonoboer og chimpanser, som vi deler 98,7 procent af vore gener med;"21 men vi kan i princippet og i høj grad med lige så stort udbytte søge andre steder som fx blandt fisk, fugle, hvaler og lignende, fordi gensammensætning i sig selv måske ikke er helt så afgørende, som vi ofte har forestillet os (se Laland 2017, 16-19). Jeg stiller med andre ord spørgsmålet, om der hos dyr findes elementer, som modsvarer procession og parade blandt mennesker.

Synkroniserede handlinger eksisterer blandt en række dyr, hvor delfiner nok hører til et af de bedst kendte eksempler; men det findes overalt i dyreriget fra fisk til fugle. Evolutionært tjener det hos mange til at undgå rovdyr, fordi den synkront koordinerede gruppebevægelse beskytter den enkelte ved at gøre det uoverskueligt for det angribende dyr at målrette sit angreb mod et bestemt dyr i flokken.22 Fuglesværmen eller fiskestimen overeksponerer rovdyret med sanseindtryk. Meget tyder imidlertid også på, at det hos en række dyr skaber ikke alene øget social kommunikation, men også forbundethed eller prosocial adfærd.

Hvis man ser på menneskeaberne og her navnlig vore nærmeste blandt dem, nemlig bonoboer og chimpanser, er det svært at få øje på noget, man med rimelighed kan betegne som parader eller processioner. Ikke desto mindre finder vi også hos chimpanser og bonoboer synkroniseret adfærd i forbindelse med hilsener af frænder og afsked, ligesom det optræder i forbindelse med jagt, typisk på mindre røde colobusaber eller bavianunger, hvor hanchimpanser er i stand til at koordinere deres jagt på en sådan måde, at de i fællig kan indkredse byttet. De vil også hyppigt koordinere deres handlinger $\mathrm{i}$ forbindelse med, at en fremmed hanchimpanse

20 Det er ikke helt ulig en tanke, Karl Marx udfoldede i anden sammenhæng: "Die Anatomie des Menschen ist ein Schlüssel zur Anatomie der Affen"; se Karl Marx 1983, 39.

21 Se Boyd \& Silk 2015, 364-68.

22 Inden for social- og adfærdsvidenskaber bruges synkronisering og koordineret adfærd ofte synonymt; men man kan med fordel skelne mellem dem, så synkroniserede handlinger repræsenterer en forstærket form for koordinering, uafhængigt af om den finder sted i kraft af bioprogrammering eller kulturel påvirkning. Jeg er Jesper Sørensen tak skyldig for dette forslag, ligesom jeg i øvrigt er Sørensen stor tak skyldig for en række forbedringsforslag til denne artikel. 
kommer ind på deres territorium eller ligefrem søger optagelse i flokken. Enten vil de true den bort eller også foretage en regulær lynchning. ${ }^{23}$

De synkroniserede handlinger hos chimpanser, der imidlertid kommer tættest på parade og procession, er deres lejlighedsvise karnevalsagtige 'fester'. Når frænder kommer sammen, synkroniserer de undertiden kropslige handlinger ved at hyle og skrige i fællesskab (den typiske chimpanse-hooting) og danse rundt. Denne kraftige følelsesudladning er samtidig med til at binde dem sammen i gruppen, fordi der hyppigt indtræder en følelsesudveksling i forbindelse med synkronisering. Ikke alene forårsager spejlneuroner en refleksion af de andres specifikke følelser hos en selv og bidrager derved til at skabe prosocial adfærd (jf. Nummenmaa et al. 2012), ${ }^{24}$ men der sker også en aktivering af parallelle hjernesystemer, som synkroniseres (se Dimberg \& Thunberg 1998). Denne ekstremsynkronisering skaber dels fællesskabsfølelse, dels øget forståelse for de andre (se Laland 2017, 278f.). Eksistensen af spejlneuroner både hos abekatte og menneskeaber er vigtig, for den gør det muligt at forstå, hvorfor navnlig de sidste i vid udstrækning også i bestemte sammenhænge griber til synkroniserede adfærdsmønstre og derigennem skaber interpersonlige relationer, som er gavnlige for gruppen (jf. de Waal 2013, 213). Disse forhold udgør i min optik en meget væsentlig forudsætning for at forstå den hominine udvikling. ${ }^{25}$ De voldsomme og larmende synkroniserede karnevalistiske følelsesudladninger hos chimpanser har formentlig været helt parallelle hos vore fjerne forfædre; men de har haft negativ betydning, da den hominine gren for ca. fire millioner år siden forlod skovarealerne og begav sig ud på savannen. Støj og larm tiltrækker rovdyr. Til gengæld har den naturlige selektion haft noget at virke på i forhold til prosocial adfærd, som har været helt afgørende for at overleve på savannen. Følelsessynkronisering og derved øget forståelse for ikke alene de andre i gruppen, men også for gruppen selv, har bidraget til at præge homininerne mod en mere fællesskabsorienteret form for liv, som igen har været betydningsfuld for den efterfølgende evolutionære udvikling. Jo mere man kan præge homininer i retning af fællesskab og gruppeorientering, desto mere egnede gør man dem til at være de sociale væsener, som vi er i dag. I den sammenhæng har synkroniseret adfærd spillet en helt afgørende rolle. Mennesker bliver ganske enkelt mere samarbejdsvillige, når de indgår i synkroniseret adfærd (se Henrich 2016, 160f.).

23 Jeg er i forståelse af navnlig chimpansers evne til koordinerede handlinger og deres karnevalistiske fester afgørende inspireret af Alexandra Maryanski, som jeg per e-mail har kommunikeret med om spørgsmålet. Derudover henviser jeg til Turner, Maryanski, Petersen \& Geertz 2017 for en mere fyldig drøftelse.

24 Betydningen af spejlneuroner er omdiskuteret; men fra det tidspunkt, man konstaterede eksistensen af dem hos abekatte og aber, har de fået en stadig større betydning i forståelsen af efterligning blandt abekatte og hominoider. De udgør hjerneceller, som aktiveres, når personer udfører handlinger, og når de samme personer ser andre udføre de samme handlinger. Derfor er de afgørende i forhold til at styrke og fremme social imitation. Se Rizzolatti \& Craighero 2004, som fortsat er udgangspunkt for diskussionen af spejlneuroner og deres betydning.

25 Der findes efterhånden en righoldig litteratur om relationen mellem synkronisering og ritualisering, se fx Xygalatas et al. 2011; Konvalinka et al. 2011; Reddish et al. 2014. 
Jeg hævder således ikke, at chimpanser og bonoboer går i procession eller parade. Det, nærmeste vi kommer det, gælder delfiner og enkelte fugle som fx pingviner. Jeg argumenterer for, at baggrunden for parade og procession skal findes i synkroniseret adfærd, som er udbredt i det øvrige dyrerige. I jagt, hilseritualer og karnevalistiske fester hos chimpanser finder vi imidlertid noget, som den naturlige selektion har kunnet virke på og som ad en lang evolutionær vej er blevet til parader og processioner. Der findes i dag en righoldig forskning, som demonstrerer, hvordan adfærdssynkronisering fører til følelses- og hjernesystemsynkroniseringer (hos abekatte, hominider og homininer forstærket gennem eksistensen af spejlneuroner, se særligt Sumpter 2010). Det bidrager igen til øget prosocial adfærd og villighed til at tilgodese gruppen på bekostning af en selv. Skal vi forstå udbredelsen af parader og processioner, er det her, vi må begynde. Det gælder her, som Dobzhansky sagde i et berømt foredrag holdt i 1972, at "intet i biologien giver mening undtagen i lyset af evolutionen" (1973). Jeg deler synspunktet, men udstrækker det til også at indbefatte den del af biologien, vi plejer at kalde kultur. Det gælder helt på samme måde i forhold til kulturen: Intet i kulturen giver mening undtagen i lyset af evolutionen. Men det sidste er selvfølgelig med den klare tilføjelse, at så såre vi begynder at tale om kultur forstået som læring mellem og på tværs af generationer, er der andre selektionsmekanismer på spil end blot den naturlige selektion. Men det er en anden historie (se her udførligt Turner et al. 2017).

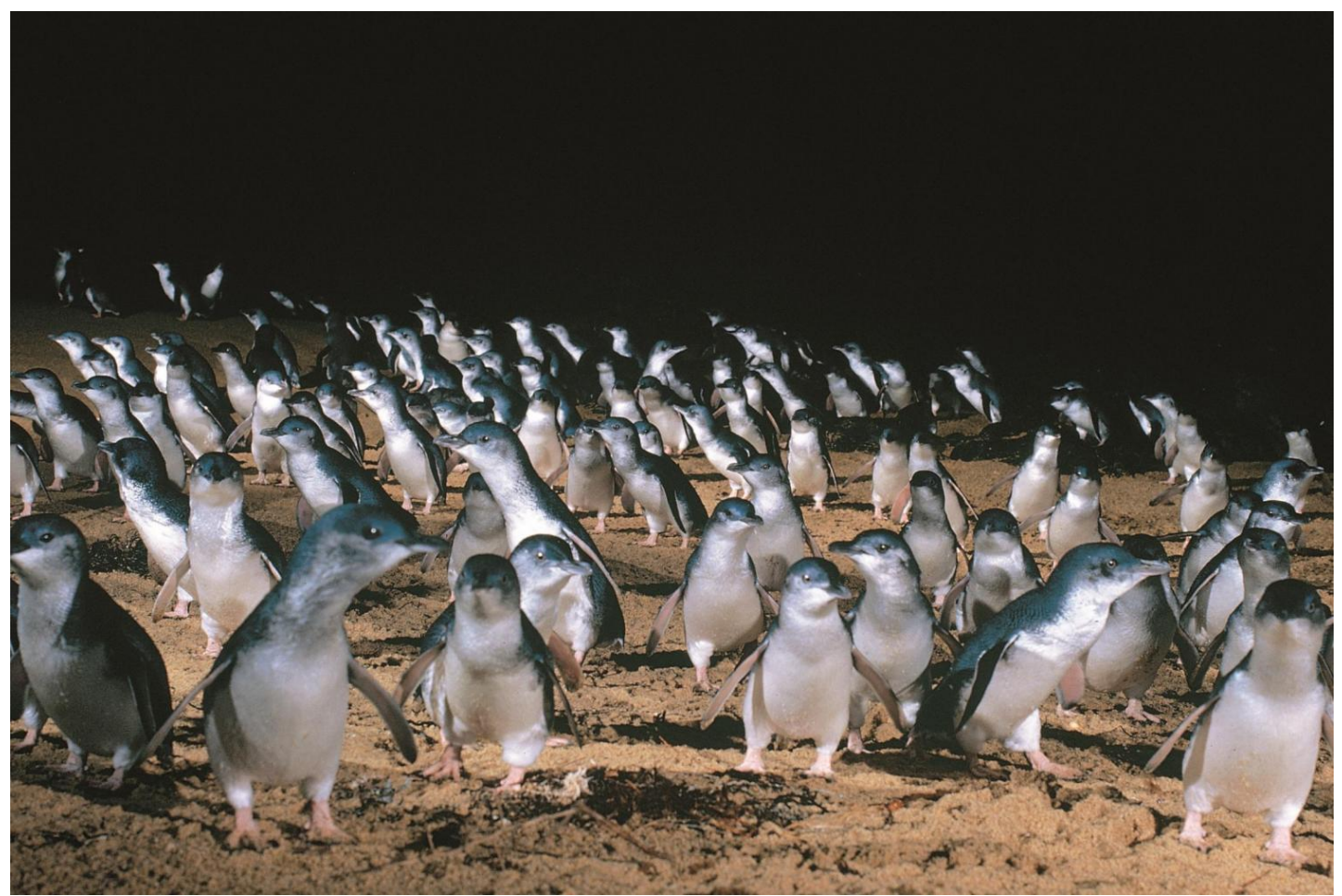

Pingviner i parade. Foto: Gray Line Tours. 


\section{Konklusion}

Jeg har i dette studie forsøgt at argumentere for tre ting. For det første at det typologisk og religionshistorisk giver god mening at sondre idealtypisk mellem parade og procession. Skønt de to fænomener i en lang række sammenhænge er sammenfaldende og derfor kan være vanskelige at skelne mellem, er der også vigtige forskelle. Hvor paraden er en indeksikal opvisning i magt og (typisk maskulin) styrke, der tjener til territorialmarkering, er processionen målrettet. Den tager sin begyndelse et bestemt sted og er orienteret mod et specifikt mål. For det andet og snævert knyttet til min første pointe foreslår jeg, at paraden som fænomen er evolutionært ældre end processionen. Hvor den første hidrører fra en jæger-samler religions-kulturel sammenhæng, opstår processionen for alvor som fænomen med by- eller de arkaiske religioner med templet som omdrejningspunkt. Templet er det kulturlige mål for processionen. For det tredje pointerer jeg, at synkroniseret adfærd udgør et centralt element i dyreadfærd generelt og at det tjener dels til beskyttelse mod rovdyr, dels til at skabe social forbundethed og prosocial adfærd. Jeg kigger i den sammenhæng på interaktions- eller udvekslingsritualer, som de ikke mindst er blevet belyst af Randall Collins, og hævder, at det er her, man skal søge den evolutionære baggrund for paraders og processioners udbredelse og sociale betydning. Endelig belyser jeg dette ud fra en evolutionær tanke, der bunder i overbevisningen, at forudsætningen for at forstå den hominine udbredelse af koordineret handlen i parader og processioner skal søges i synkroniseret adfærd generelt i dyreverdenen og i særdeleshed i hominide forudsætninger som chimpansers lejlighedsvise karnevalistiske fester. Synkronisering af handlinger fører til følelses- og hjernesystemsynkronisering, der igen leder til øget forståelse for ikke alene de andre i gruppen, men også gruppen selv. Her skabes prosocial adfærd og den form for effervescens, som Durkheim pointerede betydningen af i menneskelig kultur og religion.

Konkluderende er min tanke således, at det ikke alene analytisk giver god mening at skelne mellem parade og procession, men at de også hidrører fra forskellige religions-, social- og kulturhistoriske sammenhænge, hvorfor det religionshistorisk er rimeligt at sondre mellem dem. Jeg hævder endvidere, at processionen evolutionært skal forstås som videreudvikling af paraden, og at den derfor må antages at knytte til ved samme kognitive mekanismer, som også ligger bag paraden. Det er ikke mindst i den sammenhæng, jeg ser på hominide forudsætninger for parader og processioner hos homo sapiens sapiens, og hævder, at det er i de samme adfærdsformer blandt ikke mindst chimpanser, man skal finde forudsætningerne for de senere hominine fænomener. Processionen kan med andre ord forstås som en mere kompleks form for parade, nemlig den som hører bykulturen til til forskel fra jægersamler-kulturen.

\section{LITTERATUR}

Astrup, Elisabeth

2016 “Kropsberøring. Du må aldrig være bange for at røre," Politiken 1.05, 6. 
Barber, E.J.W.

1992 "The Peplos of Athena," in: Jenifer Neils, ed., Goddess and Polis. The Panathenaic Festival in Ancient Athens, Hood Museum of Art, Princeton: Princeton University Press, 103-117.

Beard, Mary

2007 The Roman Triumph, Cambridge, MA: The Belknap Press of Harvard University Press. https://doi.org/10.4159/9780674020597

2010 The Parthenon, London: Profile Books.

Bellah, Robert, N.

2011a "Nothing Is ever Lost: an Interview with Robert Bellah," The Immanent Frame. Secularism, religion and the public sphere, tilgængelig på: http://blogs.ssrc.org/tif/2011/09/14/nothing-is-ever-lost/ (set 28.04 2017).

2011b Religion in Human Evolution: From the Paleolithic to the Axial Age, Cambridge, MA: The Belknap Press of Harvard University Press. https://doi.org/10.4159/harvard.9780674063099

Boedeker, Deborah \& Kurt Raaflaub, eds.

1998 Democracy, Empire and Arts in Fifth-Century Athens, Cambridge, MA: Harvard University Press.

Boyd, Robert \& Joan B. Silk

2015 How Humans Evolved. 7th Edition, New York: W.W. Norton.

Bremmer, Jan

1999 Greek Religion, Greece \& Rome. New Surveys in the Classics 24, Cambridge: Cambridge University Press.

Burkert, Walter

1983 Homo Necans. The Anthropology of Ancient Greek Sacrificial Ritual and Myth, Berkeley: UCL Press.

Collins, Randall

2004 Interaction Ritual Chains, Princeton Studies in Cultural Sociology, Princeton: Princeton University Press.

Connelly, Joan B.

1996 "Parthenon and Parthenoi: A Mythological Interpretation of the Parthenon Frieze," American Journal of Archaeology 100 (1), 53-80. https://doi.org/10.2307/506297

Darwin, Charles

1936 The Origin of Species by Means of Natural Selection or the Preservation of Favored Races in the Struggle for Life $\mathcal{E}$ The Descent of Man and Selection in Relation to Sex, New York: The Modern Library.

Dobzhansky, Theodosius

1973 "Nothing in Biology Makes Sense except in Light of Evolution," The American Biology Teacher 35 (3), 125-129. https://doi.org/10.2307/4444260

Durkheim, Émile

2007 Les Formes élémentaires de la vie religieuse, CNRS Éditions, Paris: CNRS.

Ebner, Martin

1991 Leidenslisten und Apostelbrief. Untersuchungen zu Form, Motivik und Funktion der Peristasenkataloge bei Paulus, FZB 66, Würzburg: Echter Verlag.

Ehrenreich, Barbara

2007 Dancing in the Streets. A History of Collective Joy, London: Granta Books.

Fitzgerald, John T.

1988 Cracks in an Earthen Vessel. An Examination of the Catalogues of Hardships in the Corinthian Correspondence, SBL Dissertation Series 99, Atlanta, GA: Scholars Press.

Hadot, Pierre

1995 Qu'est-ce que la philosophie antique?, Paris: Gallimard.

2001 La philosophie comme manière de vivre. Entretiens avec Jeannie Carlier et Arnold I. Davidson, Itinéraires du savoir, Paris : Michel Albin.

2002 Exercises spirituels et philosophie antique, Bibliothèque de l'Évolution de l'Humanité, Paris: Albin Michel. 
Henrich, Joseph

2016 The Secret of Our Success. How Culture Is Driving Human Evolution, Domesticating Our Species and Making Us Smarter, Princeton: Princeton University Press. https://doi.org/10.1515/9781400873296

Irons, William

2001 "Religion as hard-to-fake Signs of Commitment", in: William Irons og Randolph M. Nesse, eds., The Evolution of Commitment, New York: Russell Sage Foundation, 292-309.

Konvalinka, Ivana et al.

2011 "Synchronized arousal between performers and related spectators at a fire-walking ritual", Proceedings of the National Academy of Sciences (PNAS) 108 (20), 8514-19. https://doi.org/10.1073/pnas.1016955108

Laland, Kevin. N.

2017 Darwin's Unfinished Symphony. How Culture Made the Human Mind, Princeton: Princeton University Press.

Marx, Karl

1983 "Einleitung zu den Grundrissen der Kritik der politischen Ökonomie", Karl Marx Ökonomische Manuskripte 1857/1858. Karl Marx Friedrich Engels Werke. Band 42, Berlin: Dietz Verlag.

McNeill, William H.

1995 Keeping Together in Time. Dance and Drill in Human History, Cambridge, MA: Harvard University Press.

Neils, Jenifer

1992 "The Panathenaia: an Introduction", in: eadem, ed., Goddess and Polis. The Panathenaic Festival in Ancient Athens, Hood Museum of Art, Princeton: Princeton University Press, 13-27.

2001 The Parthenon Frieze, Cambridge: Cambridge University Press.

Nietzsche, Friedrich

1985 Friedrich Nietzsche. Werke in vier Bänden, Band IV, Salzburg: Verlag das Bergland-Buch.

Nummenmaa, Lauri et al.

2012 "Emotions promote social interaction by synchronizing brain activity across individuals", WPNAS June 12, 109 (24), 9599-9604.

Parker, Robert

1997 Greek Religion. A History, Cambridge: Clarendon Press.

Petersen, Anders Klostergaard

2008 "Genskrevet Skrift", in: Anders Klostergaard Petersen, Jesper Hyldahl \& Einar Thomassen, eds., Mellem venner og fjender. En folkebog om Judasevangeliet, tidlig kristendom og gnosis (Antikken og kristendommen 6), Frederiksberg: Anis, 39-80.

2017a “Plato's Philosophy - why not just Platonic Religion?", in: Anders Klostergaard Petersen \& George van Kooten, eds., Religio-Philosophical Discourses in the Mediterranean World: From Plato, through Jesus, to Late Antiquity, Ancient Philosophy and Religion 1, Leiden: Brill, 9-36. https://doi.org/10.1163/9789004323131_003

2017b "Dissolving the Religio-Philosophy Dichotomy in the Context of Ancient Jewish Paideia: Wisdom of Solomon, 4 Maccabees, and Philo", in: Gabriele Boccacini \& Jason Zurawski, eds., Second Temple Jewish Paideia in Context, BZNW, Berlin: De Gruyter, 185-204.

2017c “Paul's Use of Pistis/Pisteuein as Epitome of Axial Age Religion", in: Antonio Cimino \& GertJan Vanderheiden, eds., Saint Paul in Philosophy, Berlin: De Gruyter, 219-36.

2017d "Zur Zeit wird hier das Raum: a Cultural Evolutionary Perspective on Paul and His Religion Epitomised by His Letters", in: Gerhard van Heever, ed., Spatialising Practices, Leiden: Brill under udgivelse.

2018 "Probing Individualisation and the Quest for Individuals in Light of a Biocultural Evolutionary Perspective", in: Jörg Rüpke, ed., Religious Individualization: Types and Cases. Historical and CrossCultural Explorations, Tübingen: Mohr-Siebeck - under udarbejdelse.

Poplutz, Uta

2004 Athlet des Evangeliums. Eine motivgeschichtliche Studie zur Wettkamfpmetaphorik bei Paulus, Herders 
Biblische Studien 43, Freiburg: Herder.

Reddish, Paul, Joseph Bulbulia \& Ronald Fischer

2014 “Does Synchrony Promote Generalized Pro-Sociality?", Religion, Brain E Behavior 4 (1), 3-19. https://doi.org/10.1080/2153599X.2013.764545

Renfrew, Collin

2009 "Situating the Creative Explosion: Universal or Local?", in: Colin Renfrew og Iain Morley, eds., Becoming Human. Innovation in Prehistoric Material and Spiritual Culture, Cambridge: Cambridge University Press, 74-92.

Rizzolatti, Giacomo \& Laila Craighero

2004 "The Mirror-Neuron System", The Annual Review of Neuroscience 27 (1), 169-192. https://doi.org/10.1146/annurev.neuro.27.070203.144230

Schmidt, Klaus

2006 Sie bauten die ersten Tempel. Das rätselhafte Heiligtum der Steinzeitjäger. Die archäologische Entdeckung am Göbekli Tepe, München: Becks Verlag.

Smith, Mark

2017 Following Osiris. Perspectives on the Osirian Afterlife from Four Millenia, Oxford: Oxford University Press. https://doi.org/10.1093/acprof:oso/9780199582228.001.0001

Sosis, Richard

2000 "Costly Signaling and Torch Fishing on Ifaluk Atoll", Evolution and Human Behavior 21 (4), 22344. https://doi.org/10.1016/S1090-5138(00)00030-1

2003 "Signaling, Solidarity, and the Sacred: The Evolution of Religious Behavior", Evolutionary Anthropology 12 (6), 264-74. https://doi.org/10.1002/evan.10120

Thunberg, Ulf \& Dimberg, Monika

1998 "Rapid facial reactions to emotional facial expressions", Scandinavian Journal of Psychology 39 (1), 39-45. https://doi.org/10.1111/1467-9450.00054

Turner, Jonathan et al.

2017 The Emergence and Evolution of Religion: By Means of Natural Selection, London: Routledge - under udgivelse.

Sumpter, David J. T.

2010 Collective Animal Behavior, Princeton: Princeton University Press. https://doi.org/10.1515/9781400837106

Versnel, Henk

1970 An Inquiry into the Origin, Development and Meaning of the Roman Triumph, Leiden: Brill.

Waal, Frans B.M. de

2013 The Bonobo and the Atheist. In Search of Humanism among the Primates, New York: W.W. Norton.

Weber, Max

1963 "Zwischenbetrachtung”, in: idem, Gesammelte Aufsätze zur Religionssoziologi I (fünfte photomechanisch gedruckte Auflage), Tübingen: Mohr-Siebeck, 536-73.

Xygalatas, Dimitris et al.

2011 "Quantifying Collective Effervescence: Heart-rate dynamics at a fire-walking ritual", Communicative E Integrative Biology 4 (6), 735-38. https://doi.org/10.4161/cib.17609

Zahavi, Amotz

1975 "Mate Selection - a Selection for Handicap", Journal of Theoretical Biology 53 (1), 205-14. https://doi.org/10.1016/0022-5193(75)90111-3

1977 "The Cost of Honesty (Further Remarks on the Handicap Principle)", Journal of Theoretical Biology 67 (3), 603-05. https://doi.org/10.1016/0022-5193(77)90061-3

Anders Klostergaard Petersen, professor MSO, Afdeling for Religionsvidenskab, Aarhus Universitet akp@cas.au.dk 